УДК 616.1/4:614.253.2(477.84)

DOI 10.11603/1811-2471.2016.v0.i4.7069

\title{
ОСОБЛИВОСТІ ФУНКЦІОНУВАННЯ СИСТЕМИ ОХОРОНИ ЗДОРОВ'Я В УМОВАХ ДЕЦЕНТРАЛІЗАЦІЇ ТА СПІВПРАЦІ З ОБ'ЄДНАНИМИ ТЕРИТОРІАЛЬНИМИ ГРОМАДАМИ НА ПРИКЛАДІ ТЕРНОПІЛЬСЬКОЇ ОБЛАСТІ
}

\author{
๑л. С. Бабінець, І. О. Боровик, Г. Г. Кміта
}

ДВНЗ «Тернопільський державний медичний університет імені І. Я. Горбачевського МОз Украӥни»

РЕЗЮМЕ. У статті проаналізовано загальний стан забезпечення населення Тернопільської області лікувально-профілактичними закладами охорони здоров'я, висвітлено перші етапи процесу проведення реформ з децентралізації та створення об'єднаних територіальних громад області. Визначено, що найефективнішим шляхом оптимізації мережі лікувально-профілактичних закладів та ліжкового фонду зокрема $\epsilon$ формування єдиного медичного простору, в основу якого покладена інтеграція закладів охорони здоров'я, що перебувають у власності різних територіальних громад та різних відомств.

КЛючОВІ СЛОВА: система охорони здоров'я, реформа, децентралізація.

Вступ. Будь-які реформи - це приведення до показника ефективності, а саме - забезпечення кращої якості при менших затратах $[1,2]$. Цього року остаточно узгоджене питання щодо передачі повноважень з надання послуг первинної ланки медицини на базовому рівні, на рівні об'єднаних територіальних громад [3]. Об'єднані громади отримали можливість самостійно розвивати систему надання первинних медичних послуг на своїй території. Також сформовано методику формування мережі вторинної ланки охорони здоров'я - госпітальних округів, які мають почати функціонувати вже з 1 січня 2017 року [4]. Ці кроки розв'яжуть існуючі проблеми зі створення мережі якісних медичних послуг в об'єднаних громадах, а також узгодять дії центральних органів виконавчої влади і місцевого самоврядування у процесі подальшого реформування медичної галузі [5].

Основною метою таких змін $\epsilon$ модернізація медичної інфраструктури, а також перехід на оптимальну модель надання медичних послуг в державі, створення єдиного медичного простору, де пацієнт може отримати якісну послугу в будь-якому місці країни [6].

Практичне виконання поставлених завдань $\epsilon$ непростим та потребує повного розуміння проблеми, а також тісної співпраці між громадами та структурами охорони здоров'я різних рівнів [5].

Мета дослідження - висвітлити основні результати проведення реформ системи охорони здоров'я в Тернопільській області в умовах децентралізації та окреслити основні напрямки вирішення наявних проблем.

Матеріал і методи дослідження. Були використані статистичні дані Тернопільської області, застосовані аналітичний, бібліосемантичний методи, а також метод системного підходу.

Результати й обговорення. Тернопільська область розташована у західній частині України,

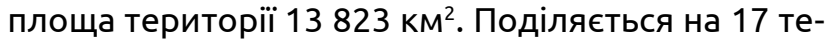
риторіально-адміністративних районів, в яких розміщено 1057 населених пунктів, і м. Тернопіль. її географічне розташування, природно-кліматичні умови, стан довкілля, густота населених пунктів залишаються одними із найблагополучніших для проживання, порівняно з іншими регіонами України.

Чисельність постійного населення становить 1066685 осіб, і впродовж останніх років реєструється зменшення в абсолютних цифрах щорічно в межах 6-7 тис. осіб. Для області характерна висока питома вага населення, що проживає у сільській місцевості, це - 55,8\%. У віковій структурі спостерігається подальша тенденція до постаріння населення та збільшення демографічного навантаження на осіб працездатного віку, яке складає 704 на тисячу осіб, у тому числі в містах - 633, у селах 764. Демографічна ситуація та стан здоров'я населення залишаються складними. За останні роки намітилась тенденція до зниження показника народжуваності, але наявна й позитивна тенденція до зменшення дитячої смертності. Проте реєструється збільшення показника загальної смертності та негативного природного приросту.

Для забезпечення динамічного спостереження та планового лікування хворих в області створена достатня мережа медичних установ. Загальна мережа на первинному рівні складається із 18 центрів первинної медико-санітарної допомоги (ЦПМСД), з них 16 окремих юридичних осіб, 2-в складі поліклінічних відділень центральних районних лікарень (ЦРЛ). У складі ЦПМСД функціонує 188 амбулаторій загальної практики-сімейної медицини (АЗПСМ), 650 фельдшерсько-акушерських (ФАП) і фельдшерських пунктів, а також 12 окремих АЗПСМ, 84 ФАПів і фельдшерських пунктів, 7 дільничних лікарень. На 
вторинному рівні загальна мережа представлена 13 районними та 16 ЦРЛ, 7 міськими закладами охорони здоров'я та 11 обласними лікарнями в сільських адміністративних районах. На третинному рівні в області функціонує 8 обласних лікувальних закладів із стаціонарами. Окрім цього, в області функціонує Центр екстреної медичної допомоги, медицини катастроф та 5 санаторіїв обласного підпорядкування, з них 4 дитячих санаторії та 1 дорослий протитуберкульозний санаторій.

Якщо оцінювати наявну мережу амбулаторно-поліклінічних закладів, то необхідно сказати, що на рівні первинної ланки в області пріоритетно проводились заходи з впровадження сімейної медицини. За останні роки 28 закладів охорони здоров'я було реорганізовано в АЗПСМ, також при всіх ЦПМСД створені міські амбулаторії $[7,8]$.

Рівень забезпеченості населення стаціонарними ліжками в розрізі профілів показує незначне перевищення обласного показника над державним за наступними профілями ліжок для дорослих: неврологічні, загальні інфекційні, хірургічні, травматологічні, отоларингологічні.

Найбільші резерви до оптимізації вбачаємо саме на рівні районних лікарень шляхом об'єднання вузькоспеціалізованих ліжок у складі єдиних загальнохірургічних відділень, приведення до нормативів інших ліжок, уникнення дублювання на рівні центральних районних та районних лікарень (загальнохірургічні, акушерські), що в загальному дасть можливість вивільнити надлишкові ліжка.

На нашу думку, раціональним $є$ проведення подальшого реформування мережі малопотужних лікарняних закладів, а саме дільничних лікарень, експлуатація яких, як правило, має медико-соціальний характер і $\epsilon$ економічно затратною, оскільки доводиться утримувати цілодобові пости, харчоблоки та ін. в той час, коли в області функціонує 7 дільничних лікарень з достатньою потужністю. Доцільно проводити реорганізацію таких закладів в АЗПСМ 3 ліжками денного стаціонару, що значно зекономить бюджетні кошти. За останній рік в Тернопільській області було реорганізовано чотири таких заклади в АЗПСМ з ліжками денного стаціонару. У планах оптимізації на Тернопіллі є пропозиції щодо переведення дільничних лікарень у медико-соціальні установи та амбулаторії. Але необхідно зазначити, що такі кроки є непопулярними і викликають супротив населення, тому органи місцевого самоврядування йдуть на них неохоче.

Управління охорони здоров'я Тернопільської ОДА розробило обласну програму оптимізації мережі, якою передбачено в перспективі створення на рівні районів територіальних медичних о6'єднань (госпітальних округів) з концентрацією спеціалізованої медичної допомоги, що стало можливим при проведенні адміністративної реформи. На І етапі пропонується сформувати 3 територіально-медичні округи на базі Чортківського, Кременецького районів та м. Тернополя [6].

Важливим шляхом оптимізації мережі лікувально-профілактичних закладів та ліжкового фонду зокрема $є$ формування єдиного медичного простору, в основу якого покладена інтеграція закладів охорони здоров'я, що перебувають у власності як різних територіальних громад, так і у підпорядкуванні різних відомств.

В обласному центрі практично проведена інтеграція лікарняних закладів, що підпорядковані Тернопільському міськвиконкому та обласному управлінню охорони здоров'я.

На виконання Закону України «Про децентралізацію влади та створення добровільних об'єднаних територіальних громад" в Тернопільській області створено найбільшу кількість об'єднаних територіальних громад - 26, (всього по Україні - 159) [6].

3 метою зменшення витрат на адміністративно-управлінський та технічний персонал доцільно створити міжрайонні (міжтериторіальні, окружні) ЦПМСД, які будуть виконувати функції організації, координації роботи медичних закладів у громадах, а також юридичної та навчальної підтримки.

На практиці децентралізація повинна стати не лише формальною передачею повноважень і коштів на місця. Основним критерієм успішності реформи повинна стати якість надання допомоги та задоволеність нею населення. У зв'язку з чим вважаємо за доцільне продовжити створення лікарських АЗПСМ на базі ФАПів, які обслуговують більше 1000 населення, завершити створення ЦПМСД як окремих юридичних осіб, відпрацювати питання співпраці з територіальними громадами.

Висновки. Протягом першого півріччя 2016 року на Тернопільщині успішно проводяться заплановані заходи щодо децентралізації в сфері охорони здоров'я на фоні ефективної співпраці з територіальними громадами. При цьому на практиці підтверджено, що найефективнішим шляхом оптимізації мережі лікувально-профілактичних закладів та ліжкового фонду зокрема $\epsilon$ формування єдиного медичного простору, в основу якого покладена інтеграція закладів охорони здоров'я, що перебувають у власності різних територіальних громад та відомств.

У перспективі подальших досліджень актуальним є визначення остаточного механізму розподілу коштів та затвердження бюджету на 2017 рік уже в рамках прийнятої концепції, а також державних важелів, які дозволять налагодити фінансування первинної, вторинної і третинної ланок медицини. 
Огляди літератури, оригінальні дослідження, погляд на проблему

\section{ЛІТЕРАТУРА}

1. Кульчицький М. І. Децентралізація як основа розбудови регіонів та підвищення фінансового забезпечення територій / М.І.Кульчицький, О.В.Заброцька // Бізнесінформ. - 2016. - № 4. - С. 88-95.

2. Планування та управління фінансовими ресурсами територіальної громади / О. Кириленко, Б. Малиняк, В. Письменний, В. Русін / Асоціація міст України -К. : ТОВ «ПІДПРИЕМСТВО «ВІЕНЕЙ», 2015. - 396 с.

3. Про затвердження Державної стратегії регіонального розвитку на період до 2020 року: Постанова Кабінету Міністрів України від 06.08.2014 р. № 385 / Законодавство України [Електронний ресурс]. - Режим доступу: http://zakon5.rada.gov.ua/laws/ show/385-2014-\%D0\%BF

4. Національна стратегія реформування системи охорони здоров'я в Україні на період 2015 - 2020 років - [Електронний ресурс]. - Режим доступу: URL: http://healthsag.org.ua/wp-content/uploads/2014/11/ Strategiya_UKR.pdf). - Назва з екрана.

5. Павлюк К.В. Децентралізація в системі фінансування охорони здоров'я / К.В. Павлюк, О.В. Степанова // Фінанси України. - 2015. - № 4. - С. 67-85.

6. Децентралізація влади. Реформа медицини [Електронний ресурс]. - Режим доступу: URL: http:// decentralization.gov.ua/reforms/item/id/6). - Назва 3 екрана.

7. Досягнення і проблеми надання медичної допомоги населенню Тернопільщини з акцентом на первинну ланку / Л. С. Бабінець, О. О. Ткач, Л. М. Матюк [та ін.] // Сімейна медицина. - 2015. - № 3 (59). - С. 28-31.

8. Сімейна медицина на Тернопільщині: успіхи, проблеми, шляхи вирішення / Л. С. Бабінець, О. О. Ткач, Л. М. Матюк [та ін.] // Сімейна медицина. - 2014. - № 6 (56). - С. 4-6.

\title{
PECULIARITIES OF PUBLIC HEALTH SYSTEM IN CONDITIONS OF DECENTRALIZATION AND COOPERATION WITH THE UNITED TERRITORIAL COMMUNITIES ON THE EXAMPLE OF TERNOPIL REGION
}

\author{
OL. S. Babinets, I. O. Borovyk, H. H. Kmita \\ I. Horbachevsky Ternopil State Medical University
}

SUMMARY. The article analyzes the general state of health facilities providing public health of Ternopil region, highlights the first stages of reform on decentralization and the creation of united communities of the region. It was determined, that the most effective way to optimization of the health care institutions and hospital beds in particular is the formation of a single medical space, which is based on the integration of health facilities that are owned by different local communities and various agencies.

KEY WORDS: public health system, reform, decentralization. 